\title{
Evaluation of Some Water Management Methods on Water Productivity and Its Saving Under Onion Crop Production at Dugda District, Rift valley of Ethiopia
}

\author{
Tamasgen Mosisa* Amare Haileslassie ${ }^{2}$ \\ 1.Soil and Water Engineering Researcher, Haro Sabu Agricultural Research (IQQO) \\ 2.Senior Irrigation Researcher, International Water Management Institute (IWMI)
}

\begin{abstract}
The limitation in water availability as well as salinity and waterlogging related to over application of irrigation water resulted in low crop water productivity, which obliges to select alternative water management methods. The work compared Wetting Front Detector against Crop Water Requirement and farmers practice under onion production. A field experiment was designed in Randomized Complete Block Design, replicated five times on farmers' fields. Results were compared on the basis of application, distribution, storage and water use efficiencies, and water productivity. The results illustrate that there was a significant difference between the water used in the three methods of irrigation water management used in this manuscript. In comparison with farmer method, Crop Water Requirement saved irrigation water by $35 \%$. The Wetting Front Detector technology also saved the irrigation water by about $16 \%$ than the farmer method. On the basis of these values, the water saved by the Crop Water Requirement technique could irrigate $16.5 \%$ and the Wetting Front Detector 6-8\% more area of onion field than the farmer practice. The differences between the water optimization techniques can be accounted for by to differences in the efficiencies of application, storage and irrigation water use which vary considerably from one type of irrigation water management to another at $p<0.05$. Generally, Crop Water Requirement technique is more application efficiencies (59.06) followed by the Wetting Front Detector technique $(53.78 \%$ ) and farmer practice (49.26\%). The mean Irrigation Water Use Efficiency of Crop Water Requirement, Wetting Front Detector and Farmer Practice were 114.79, 78.38 and 54.38 respectively. The Crop Water Requirement had an storage efficiency of $65.09 \%$ which can be beneficially used by the crops while the Wetting Front Detector has efficiently store $59.78 \%$. Based on this study, Crop Water Requirement technique appears to be a promising alternative for water saving without negligible trade-off in yield.
\end{abstract}

Keywords: crop water productivity, water use efficiency, water saving, onion

DOI: $10.7176 / \mathrm{JNSR} / 10-7-04$

Publication date: April $30^{\text {th }} 2020$

\section{Introduction}

Uncertainty of future rainfall due to global warming and climate change pushes to irrigation development. But this is constrained by shrinking fresh water resources. Water is becoming increasingly scarce, creating droughts which are becoming still more serious due to changing climate conditions, especially in the rift valley areas of Ethiopia. Nowadays, there is an increasing tendency to use more irrigation water in this region, where supplemental water is needed to increase production.

Production of onion, hot pepper, tomato, potato and other vegetable crops are dominantly grown in Ethiopia. Most of those vegetable crops productivity are rather higher under irrigation than under rainfed condition. Onion (Allium cepa L.) is increasingly produced at local level. Bombay Red and Adama Red are the most preferred onion varieties in east Shoa, Bombay Red is early maturing and is suitable for local market (Amsalu et al., 2014).

Among the four - LEPA, drip, sprinkler and surface, (flood, basin, border and furrows) types of irrigation sprinkler, drip and LEPA methods are known to be efficient in maximizing water utilization; but their initial investment cost is often prohibitive and not affordable by the developing countries like Ethiopia. Under such conditions, least initial investment and yet less precise irrigation systems have to be considered. As a result, furrow irrigation method is the most widely used.

The limitation in water availability and also salinity and waterlogging related to over application of irrigation water resulted in low crop water productivity, which obliges to adopt alternative water management techniques (Lorite et al., 2007). The work compared the very useful and popular these days: a simple on-farm water optimization technology called Wetting Front Detector (WFD) against a computer program to estimate Crop Water Requirement (CWR). These techniques are required to be evaluated for their efficiency as compared to farmers practice (FP) on the basis of observation of crop condition, water use efficiency and its resultant effect on saving of water. This was done by when applying conventional furrow irrigation.

The farmers in the study area pump irrigation water from Zuway-Meki Lake, Meki irrigation scheme (developed in 1987) for intensive irrigation practice, as poor rainfall distribution during the growing season. Meki scheme was anticipated to irrigate land of 3000 ha with nine pumps installed having a discharge capacity of 764 
liters/second each. But practically, it is covering less than 1,200 ha per cropping season in the 2016. Over irrigation is among the bounding problem to cover less than half of the designed area (Zeleke et al., 2016).

The general objective of this study was to ascertain the amount of water likely to be saved and evaluating the crop and water productivity by using different on farm water optimization tools.

The specific objectives of the study include:

(i) To determine the water productivity for onion crops,

(ii) To quantify the amount of water saved under different water optimization techniques

\section{Description of the Study Area}

The study was conducted at Dugda district (1662 m.a.s.1), East Shoa, Oromia National Region state located in Ethiopian rift valley (figure 1). Meki town is the district capital.

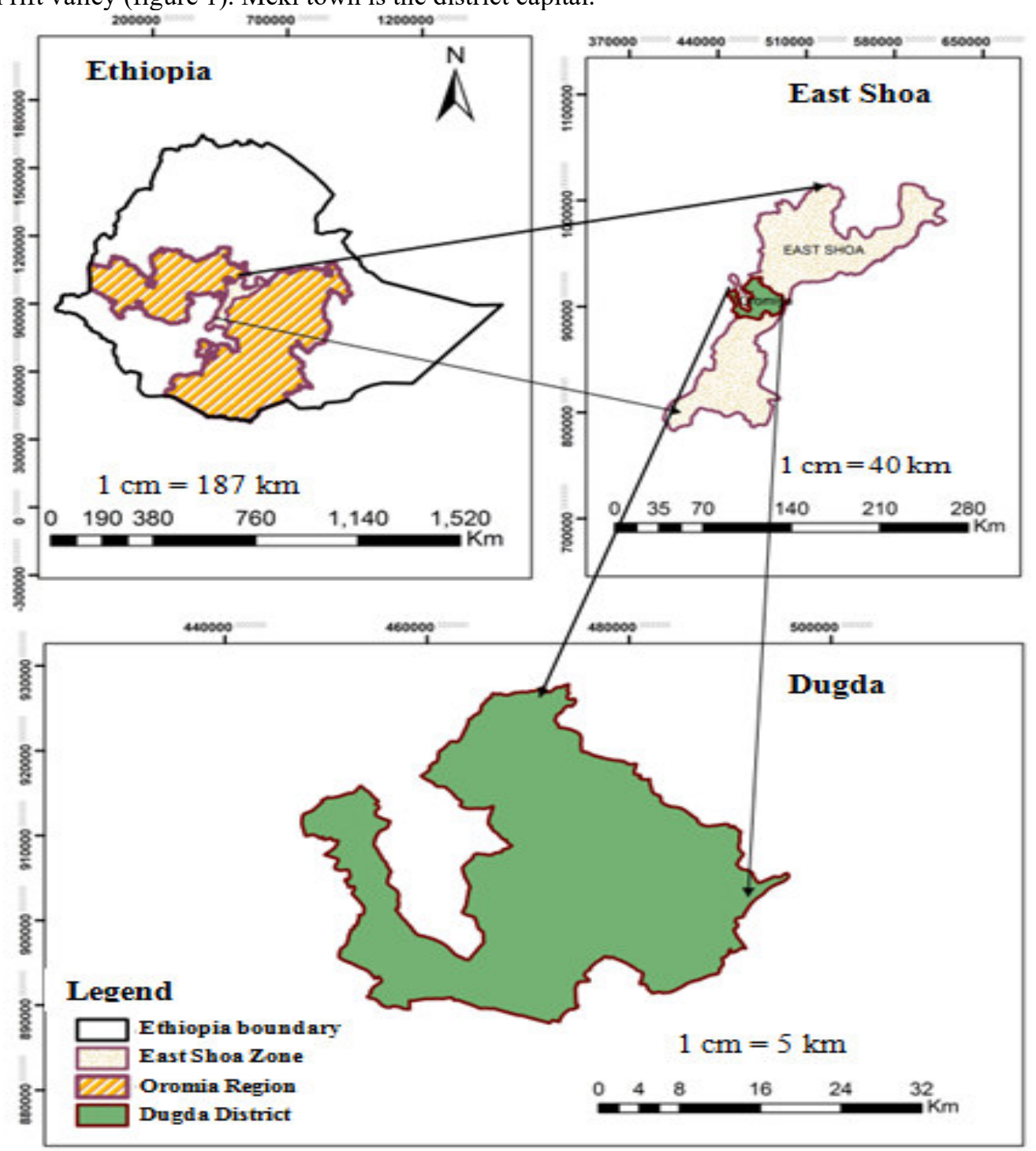

Figure 1. Location map of the study area

The climate is mild, and generally warm and temperate. The average annual temperature is $21.1^{\circ} \mathrm{C}$ (figure 2 ). Summer is much rainier, about $694.1 \mathrm{~mm}$ of precipitation falls annually. Lowest precipitation occurs in December, while the highest in July. The major soil class is generally Sandy Loam, had moderately high infiltration rate. 


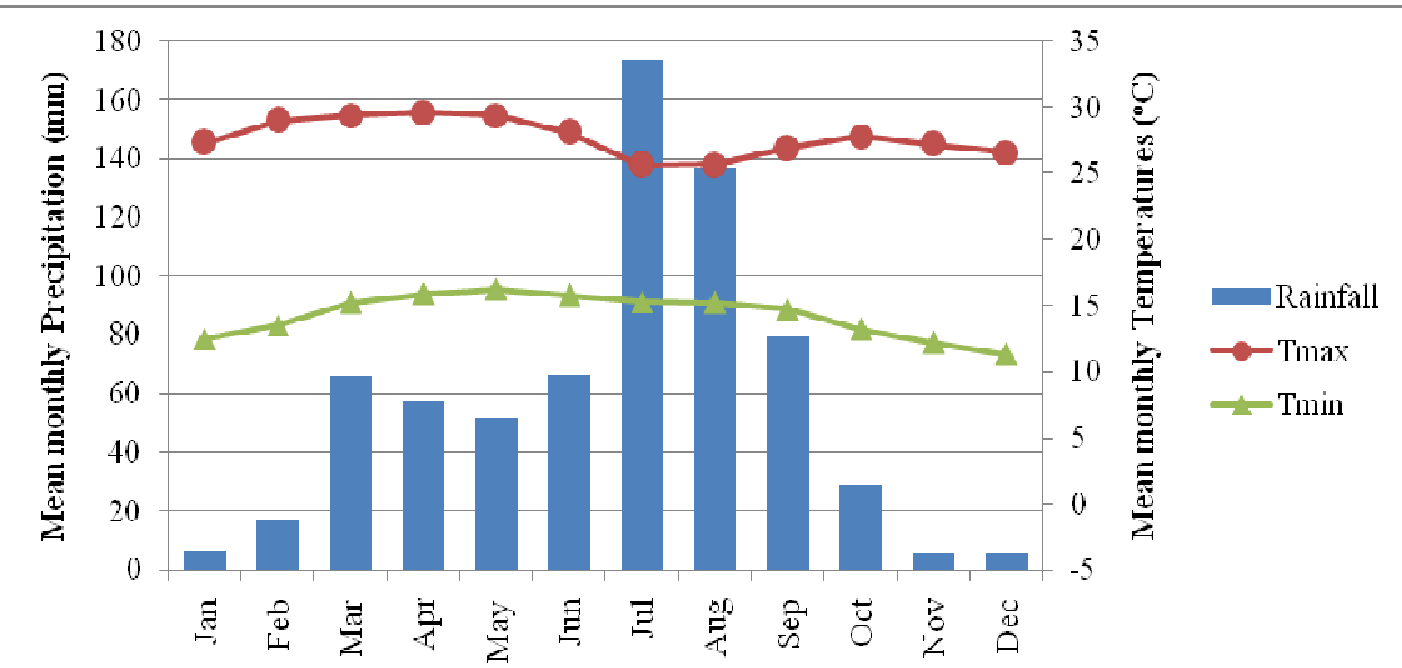

Figure 2. Dugda area weather condition

Frequent drought, and hence moisture stress is the bounding problem of the area (MoFED, 2006). It is one of the intensively irrigated areas in Ethiopia to achieve food security. Horticultural crops grown include onion, pepper, tomato, potato, shallot, haricot beans, sweet potato and papaya. Crops grown three times a year: once by rain, and twice by irrigation.

Soil infiltration rate, its physico-chemical properties, irrigation efficiency parameters and yield of the crops were directly measured in the field. Weather data were obtained from National Meteorological Service Agency. Wetting Front Detector, CROPWAT based Crop Water Requirement and Farmer methods were evaluated on the basis of observation of crops production. Randomized Complete Block Design was used. Each experimental plot had a common dimension of $10 \mathrm{~m} \mathrm{X} 5 \mathrm{~m}$ with $1 \mathrm{~m}$ free space between plots (Fig 3).

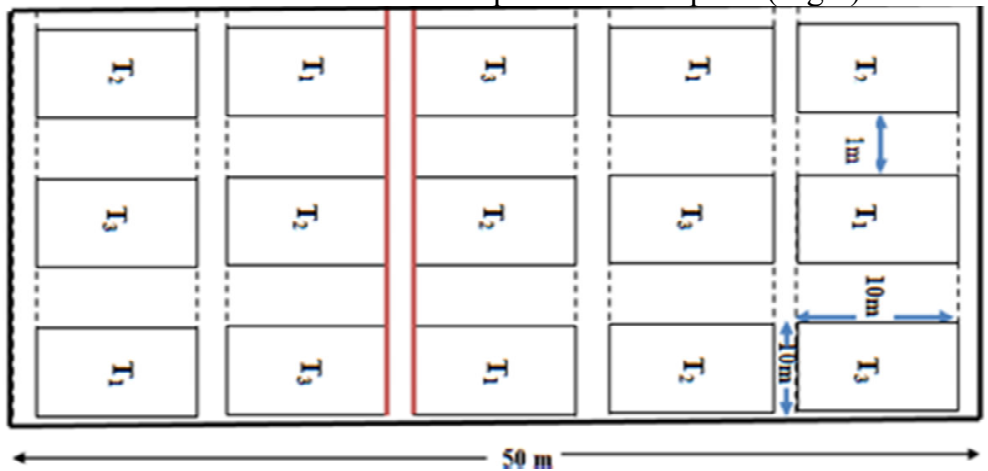

\section{Materials used:}

Infiltration rate was tested by double ring infiltrometer method, GPS for coordinate positioning, Rain gauge for precipitation. Wetting Front Detector was used to detect irrigation water, 3inch Parshall flume to measure discharges. Soil auger and core sampler for soil sampling and, plastic bag for composite soil sample collection. Measuring tape and water level were used for field layout and furrow design. Onion seeds, different chemicals (antipests, bactocides and fungicides) as well as fertilizers (DAP and UREA) were inputs used.

\subsection{Wetting Front Detectors}

A pair of detectors - buried at $1 / 3^{\text {rd }}$ and $2 / 3^{\text {rd }} \mathrm{cm}$ depth - shows the depth to which water has infiltrated into the soil. They were installed at the $3 / 4^{\text {th }}$ of the furrow length from the tertiary canal, positioned half under the furrow and half under the bed with the extension tube rising through the shoulder of the bed. When the wetting front reaches the detector, an indicator pops up which is visible on the top of the extension tubes. If the shallow detector is rarely activated it is likely that the crop is being under irrigated; whereas, if the deep detector is often activated it indicates that the crop may be over irrigated (Stirzaker et al., 2005).

\subsection{CROPWAT}

The amount of water needed to compensate the amount of water lost through evapotranspiration $\left(\mathrm{ET}_{\mathrm{c}}\right)$ requires reference evapotranspiration $\left(\mathrm{ET}_{0}\right)$ and crop coefficient $\left(\mathrm{K}_{\mathrm{c}}\right)$. Periodic reference crop evapotranspiration $\left(\mathrm{ET}_{0}\right)$ for each day of climatic record was calculated based on the modified FAO Penman-Monteith equation (Allen et al., 
1998) using FAO CROPWAT software version 8. The FAO Penman-Monteith method uses standard climatic records of solar radiation (sunshine), air temperature, humidity and wind speed for daily, weekly and monthly calculations and calculates $\mathrm{ET}_{\mathrm{o}}$, thereby determine the amount of CWR to compensate the ET loss.

where

$$
E T_{0}=\frac{0.408 \Delta\left(R_{n}-G\right)+\gamma \frac{900}{T+273} U_{2}\left(e_{s}-e_{a}\right)}{\Delta+\gamma\left(1+0.34 U_{2}\right)}
$$

$\mathrm{R}_{\mathrm{n}}=$ net radiation at the crop surface $\left(\mathrm{MJ} \mathrm{m}^{2}\right.$ day $\left.^{-1}\right)$,

$\mathrm{G}=$ soil heat flux density $\left(\mathrm{MJ} \mathrm{m}^{-2} \mathrm{day}^{-1}\right)$,

$\mathrm{T}=$ mean daily air temperature at $2 \mathrm{~m}$ height $\left({ }^{0} \mathrm{C}\right)$,

$\mathrm{U}_{2}=$ wind speed at $2 \mathrm{~m}$ height $\left(\mathrm{ms}^{-1}\right)$,

$\mathrm{e}_{\mathrm{s}}=$ saturation vapour pressure $(\mathrm{KPa})$,

$\mathrm{e}_{\mathrm{a}}=$ actual vapour pressure $(\mathrm{KPa})$,

$\left(\mathrm{e}_{\mathrm{s}}-\mathrm{e}_{\mathrm{a}}\right)=$ saturation vapour pressure deficit $(\mathrm{KPa})$,

$\Delta=$ slope vapour pressure curve $\left(\mathrm{KPa}^{0} \mathrm{C}^{-1}\right)$,

$\gamma=$ psychrometric constant $\left(\mathrm{KPa}^{0} \mathrm{C}^{-1}\right)$

Scheduling was done by CROPWAT model considering climate, soil infiltration, crop characteristics, allowable depletion level, date of planting of the crop and their growing periods. The allowable soil moisture depletion for the crop is $25 \%$ (Doorenbos and Kassam, 1996).

The net irrigation requirement $\left(\mathrm{IR}_{\mathrm{n}}\right)$ has been calculated using the CROPWAT computer program based on $I R_{n}=E T_{c}-P_{e}$. Calculation of crop water requirement, $\mathrm{ET}_{\mathrm{c}}$, using CROPWAT model over the growing season was determined from $\mathrm{ET}_{0}$ and $\mathrm{K}_{\mathrm{c}}$ as $E T_{c}=K_{c} \times E T_{0}$

The Total Available Water for each plots were also computed from bulk density, FC and PWP following equation: $d_{n e t}=(F C-P W P) \times D_{r z} \times \rho$

The application time $(\mathrm{sec})$ required to deliver the desired depth of water into each furrow was calculated using the equation $t=\frac{I_{g} \times w \times l}{6 Q}$

where $1=$ furrow length $(\mathrm{m}), \mathrm{w}=$ furrow spacing $(\mathrm{m})$, and $\mathrm{Q}=$ flow rate $(\mathrm{l} / \mathrm{s})$.

Yield, Water Productivity and Data Analysis

Amount of onion bulbs produced were collected from central ridges only for the sake of avoiding boarder effects. The results of the yields were then weighed, averaged and converted on hectare basis by multiplying the yield obtained per $\mathrm{m}^{2}$ to 10,000 .

Water productivity was estimated in terms of crop water use efficiency $\left(C W U E=\frac{Y}{E T_{c}}\right)$ and irrigation water use efficiency $\left(I W U E=\frac{Y}{I_{g}}\right)$.

The data were subjected to ANOVA using Tukey's Highly Significant Difference of Statistical Analysis Software (SAS) 9.0. Significant differences between treatment means were separated using the Fisher's LSD test at $\mathrm{P}<0.05$ significant level following Gomez and Gomez (1984) procedure.

\section{Efficiencies of Irrigation Water Optimization Techniques}

Application efficiency ( $\mathrm{E}_{\mathrm{a}}$ in \%) is calculated as (Zerihun et al., 1997) : $E_{a}=\frac{W_{s}}{W_{f}} \times 100$

where $\mathrm{W}_{\mathrm{s}}=$ water $(\mathrm{mm})$ stored in the root zone and $\mathrm{W}_{\mathrm{f}}=$ water applied $(\mathrm{mm})$ to the field.

Water storage efficiency is calculated as (Walker, 1989): $E_{r}=\frac{W_{s}}{W_{n}} \times 100$

where $\mathrm{E}_{\mathrm{r}}=$ storage efficiency $(\%), \mathrm{W}_{\mathrm{s}}=$ volume of water $(\mathrm{mm})$ added to root zone storage, $\mathrm{W}_{\mathrm{n}}=$ potential soil moisture storage volume $(\mathrm{mm})$. 


\section{Result and Discussion}

4.1. Soil Characterization -physical (Before Planting)

\begin{tabular}{|c|c|c|c|c|c|c|c|c|c|}
\hline Code & Depth $(\mathrm{cm})$ & $\begin{array}{c}\text { FC } \\
(\%)\end{array}$ & $\begin{array}{c}\text { PWP } \\
(\%) \\
\end{array}$ & $\begin{array}{c}\text { BD } \\
\left(\mathrm{g} / \mathrm{cm}^{3}\right)\end{array}$ & $\begin{array}{c}\text { TAW } \\
(\%) \\
\end{array}$ & Sand & Clay & Silt & Texture \\
\hline \multirow{2}{*}{$1701 \mathrm{HH}$} & $0-30$ & 21.76 & 12.27 & 1.29 & 122.42 & 39.95 & 24.85 & 35.20 & \multirow{2}{*}{$\mathrm{L}$} \\
\hline & $30-60$ & 25.82 & 14.39 & 1.31 & 149.73 & 38.03 & 26.70 & 35.27 & \\
\hline \multirow{2}{*}{$1703 \mathrm{AD}$} & $0-30$ & 34.28 & 20.69 & 1.40 & 190.23 & 57.78 & 14.78 & 27.44 & \multirow{2}{*}{ SL } \\
\hline & $30-60$ & 27.63 & 20.89 & 1.46 & 98.40 & 55.86 & 16.63 & 27.51 & \\
\hline \multirow{2}{*}{$1705 \mathrm{AG}$} & $0-30$ & 39.52 & 24.85 & 1.37 & 200.91 & 75.42 & 8.19 & 16.39 & \multirow{2}{*}{ SL } \\
\hline & $30-60$ & 23.4 & 22.36 & 1.49 & 15.50 & 73.50 & 10.04 & 16.46 & \\
\hline \multirow{2}{*}{ 1706AT } & $0-30$ & 22.11 & 11.68 & 1.39 & 144.98 & 65.07 & 12.33 & 22.60 & \multirow{2}{*}{ SL } \\
\hline & $30-60$ & 22.59 & 13.88 & 1.52 & 132.39 & 63.15 & 14.18 & 22.67 & \\
\hline \multirow{2}{*}{$1707 \mathrm{TM}$} & $0-30$ & 23.66 & 13.33 & 1.29 & 133.26 & 67.10 & 10.28 & 22.62 & \multirow{2}{*}{ SL } \\
\hline & $30-60$ & 28.17 & 15.71 & 1.40 & 174.44 & 65.18 & 12.13 & 22.69 & \\
\hline \multirow{2}{*}{$1708 \mathrm{BU}$} & $0-30$ & 42.52 & 24.69 & 1.28 & 228.22 & 69.19 & 8.21 & 22.60 & \multirow{2}{*}{ SL } \\
\hline & $30-60$ & 28.44 & 23.37 & 1.36 & 68.95 & 67.27 & 10.06 & 22.67 & \\
\hline \multirow{2}{*}{ 1713BB } & $0-30$ & 39.99 & 26.14 & 1.31 & 181.44 & 47.50 & 25.20 & 27.30 & \multirow{2}{*}{ SCL } \\
\hline & $30-60$ & 29.74 & 23.88 & 1.46 & 85.56 & 45.58 & 27.05 & 27.37 & \\
\hline
\end{tabular}

L $=$ Loam, SL = Sandy Loam, SCL = Sandy Clay Loam, FC $(\%)=$ Field Capacity, PWP $(\%)=$ Permanent Wilting Point, $\mathrm{BD}=$ Bulk Density, TAW = Total Available Water (\%)

The soil bulk densities varied from 1.28 to $1.52 \mathrm{~g} / \mathrm{cm}^{3}$, within the range of ideal bulk densities for plant growth (USDA, 2008). Generally TAW and the sand content were higher for the upper layer; the clay and silt content of the bottom layer are higher. According to the USDA (1994) soil textural classification, the soil classes identified were Loam, Sandy Loam and Sandy Clay Loam. More often, but small amount of irrigation water is required for such type of soil (FAO, 1989).

\subsection{Soil Characterization -Chemical (Before Planting)}

\begin{tabular}{llcccrrr}
\hline Code & Date & $\begin{array}{c}\mathbf{p}^{\mathbf{H}}\left(\mathbf{H}_{\mathbf{2}} \mathbf{O}\right) \\
1: 2.5\end{array}$ & $\begin{array}{c}\mathbf{E C} \\
(\mathrm{mS} / \mathrm{cm})\end{array}$ & $\begin{array}{c}\mathbf{O M} \\
(\%)\end{array}$ & $\begin{array}{c}\text { CEC } \\
(\mathrm{meq} / 100)\end{array}$ & $\begin{array}{c}\text { Sum of } \\
\text { cations }\end{array}$ & ESP $(\%)$ \\
\hline AG & $29 / 12 / 2015$ & 9.41 & 0.08 & 4.40 & 21.81 & 21.42 & 23.47 \\
HH & $29 / 12 / 2016$ & 9.41 & 0.08 & 4.40 & 21.81 & 21.42 & 23.47 \\
BU & $29 / 12 / 2017$ & 9.07 & 0.13 & 3.03 & 20.97 & 20.75 & 26.38 \\
AS & $29 / 12 / 2018$ & 9.07 & 0.13 & 3.03 & 20.97 & 20.75 & 26.38 \\
AM & $29 / 12 / 2019$ & 9.00 & 0.12 & 3.69 & 54.30 & 51.95 & 16.00 \\
MB & $29 / 12 / 2020$ & 8.83 & 0.30 & 3.91 & 39.57 & 39.04 & 19.32 \\
FT & $29 / 12 / 2021$ & 9.12 & 0.10 & 2.47 & 23.80 & 23.71 & 21.15 \\
\hline
\end{tabular}

EC (mS/cm) (1:2.5), O.M (\%), CEC (meq/100 gm of soil), ESP\% Sum of Cations (meq/100gm of soil)

According to the rating given by Tekalign and Haque (1991), the soil is out of preferable range for onion production (Doorenbos and Kassam, 1996; Olani and Fikre, 2010) that it is strongly alkaline. Generally, such problematic soil needs to be reclaimed before using for production. The organic matter (O.M) content also varied between 2.47 to $4.4 \%$ (in the range of very low to low according to Landon (2014) rating), that which is inadequate.

\subsection{Chemical properties of soil after harvest}

Soil $\mathrm{pH}$ is reduced from 'strongly alkaline' before planting to 'moderately alkaline' after crop harvest according to the rating made by Tekalign and Haque (1991). Higher pH under FP followed by WFD then CWR was clearly observed. Possible reason may be leaching of alkalinity (basic cations. Electrical conductivity (EC) is increased from before planting to after crop harvest. Irrigation water has direct relation with EC. 


\begin{tabular}{llrrrrrr}
\hline Code & Date & $\begin{array}{c}\mathbf{P}^{\mathbf{H}}\left(\mathbf{H}_{2} \mathbf{O}\right) \\
1: 2.5\end{array}$ & $\begin{array}{c}\mathbf{E C} \\
(\mathrm{mS} / \mathrm{cm})\end{array}$ & $\begin{array}{c}\text { OM } \\
(\%)\end{array}$ & $\begin{array}{c}\text { CEC } \\
(\text { meq/100) }\end{array}$ & Sum of cations & ESP $(\%)$ \\
\hline AG_FP & $16 / 05 / 2016$ & 8.79 & 0.35 & 1.28 & 25.61 & 21.19 & 16.97 \\
AG_WFD & $16 / 05 / 2016$ & 8.45 & 0.17 & 3.91 & 35.46 & 41.45 & 9.07 \\
AG_CWR & $16 / 05 / 2016$ & 8.22 & 0.16 & 3.93 & 44.70 & 31.46 & 8.91 \\
\hline HH_FP & $16 / 05 / 2016$ & 8.95 & 0.16 & 1.01 & 22.50 & 20.02 & 20.00 \\
HH_WFD & $16 / 05 / 2016$ & 8.87 & 0.16 & 1.06 & 24.35 & 19.56 & 19.61 \\
HH_CWR & $16 / 05 / 2016$ & 8.46 & 0.15 & 1.09 & 24.42 & 20.18 & 19.09 \\
\hline TB_FP & $16 / 05 / 2016$ & 8.15 & 0.14 & 1.35 & 20.28 & 17.03 & 14.29 \\
TB_WFD & $16 / 05 / 2016$ & 7.65 & 0.12 & 1.58 & 24.37 & 19.82 & 9.48 \\
TB_CWR & $16 / 05 / 2016$ & 7.51 & 0.11 & 1.66 & 24.77 & 21.33 & 8.28 \\
\hline FT_FP & $16 / 05 / 2016$ & 8.05 & 0.13 & 2.03 & 15.49 & 12.39 & 6.63 \\
FT_WFD & $16 / 05 / 2016$ & 7.85 & 0.09 & 2.18 & 21.72 & 16.97 & 5.76 \\
FT_CWR & $16 / 05 / 2016$ & 7.73 & 0.11 & 2.22 & 20.82 & 16.64 & 5.75 \\
\hline OF_
\end{tabular}

$\mathrm{O}=$ onion; FP, WFD and CWR are the irrigation water optimization techniques evaluated;

$\mathrm{EC}(\mathrm{mS} / \mathrm{cm}), \mathrm{O} . \mathrm{M}(\%)=$ organic matter, CEC (meq/100 $\mathrm{gm}$ soil) sum of cations $(\mathrm{meq} / 100 \mathrm{gm} \mathrm{soil})$.

Moreover, cation exchange capacity (CEC) was in the range of moderate to very high before planting. After crop harvest the range becomes moderate to high based on the rating of CEC given by Landon (2014). It's generally increased from before planting to after harvest. Possible reason may be irrigation water quality.

Infiltration rate (Figure 4).

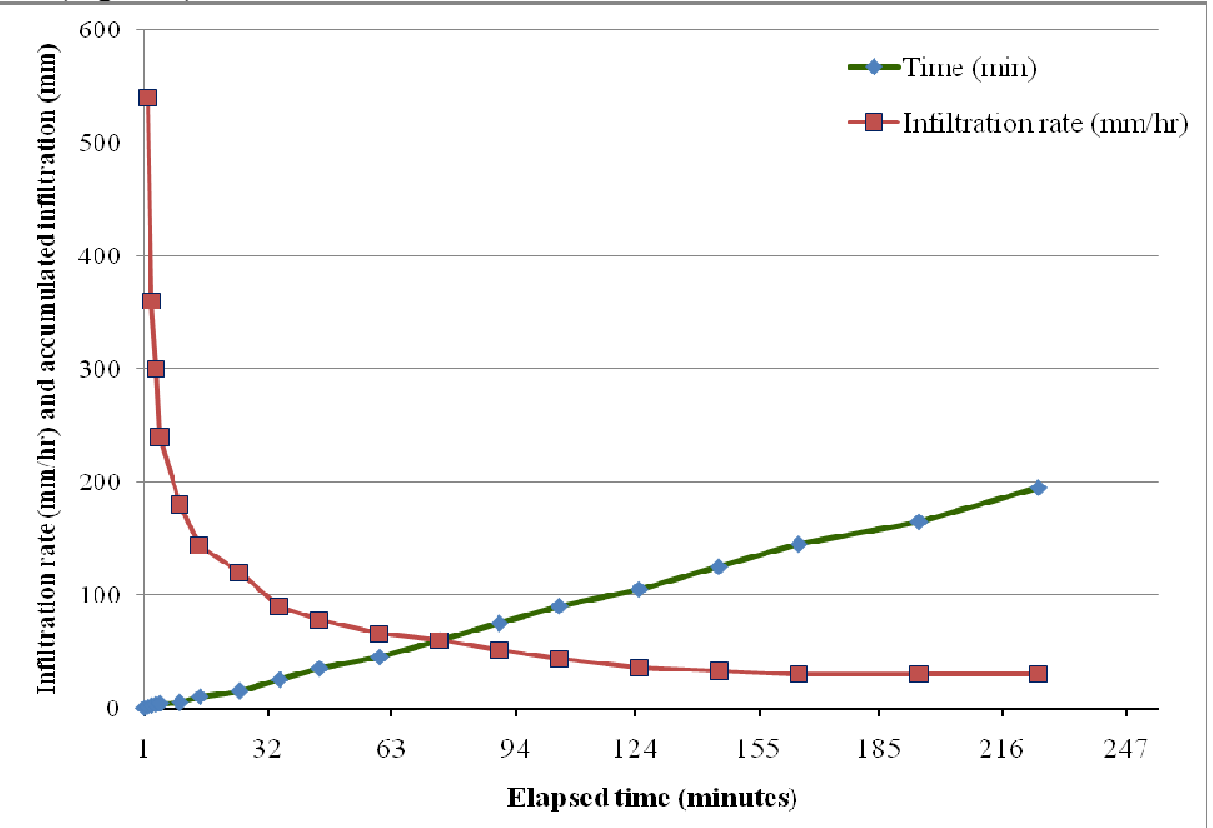

The infiltration curve indicated that the soil had initially higher Infiltration Rate (IR) $(540 \mathrm{~mm} / \mathrm{hr})$; it gradually decreases and attained its basic IR $(30 \mathrm{~mm} / \mathrm{hr})$ at about 2 hours. The result was consistent with the report of Scherer et al, (1996) that the basic infiltration rate of sandy loam soil is in the range of 20 to $30 \mathrm{~mm} / \mathrm{hr}$. The soil being Sandy Loam (Loam) and moderately high infiltration rate_had therefore, low water storage capacity.

The means of amount of water applied $\left(\mathrm{m}^{3}\right)$ for (per plot)

\begin{tabular}{|l|l|}
\hline Treatments & Onion \\
\hline CWR & $\mathbf{1 8 . 6 4}^{\mathbf{c}}$ \\
\hline WFD & $\mathbf{2 3 . 8 8}^{\mathbf{b}}$ \\
\hline FP & $\mathbf{2 8 . 6 1 ^ { \mathbf { a } }}$ \\
\hline LSD $_{0.05}$ & 4.67 \\
\hline CV & 13.51 \\
\hline SE & 2.03 \\
\hline
\end{tabular}

CWR saved 35\% more than FP. This result is in agreement with the report of Doorenbos and Kassam (1996). Maximum water applied via FIP, implies wastage. 
Impact of Irrigation Water Management on yields of Onion

\begin{tabular}{l|ll}
\hline Treatment & Marketable (t/ha) & Unmarketable (t/ha) \\
\hline CWR & $42.89^{\mathrm{a}}$ & $10.64^{\mathrm{b}}$ \\
$\mathrm{WFD}$ & $37.87^{\mathrm{b}}$ & $12.76^{\mathrm{a}}$ \\
$\mathrm{FP}$ & $31.72^{\mathrm{c}}$ & $11.36^{\mathrm{ab}}$ \\
\hline $\mathrm{LSD}_{0.05}$ & 3.56 & 2.03 \\
$\mathrm{CV}$ & 6.52 & 11.99 \\
$\mathrm{SE}$ & 1.55 & 0.88 \\
\hline
\end{tabular}

Yield is statistically different among treatments in which CWR is more important.

Effect of IWM on Water Use Efficiency and Water Productivity

IWUE is observed to be higher under CWR followed by WFD. It's Consistent with the significant improvements reported by Doorenbos and Kassam (1996).

\begin{tabular}{l|rrr}
\hline Irrigation management & IWUE & CWUE & WP \\
\hline CWR & $123.6^{\mathrm{a}}$ & $178.26^{\mathrm{a}}$ & $8.72^{\mathrm{a}}$ \\
WFD & $73.91^{\mathrm{b}}$ & $73.94^{\mathrm{b}}$ & $5.49^{\mathrm{b}}$ \\
FP & $54.33^{\mathrm{c}}$ & $54.33^{\mathrm{b}}$ & $4.05^{\mathrm{c}}$ \\
\hline CV & 18.89 & 48.29 & 15.02 \\
$\mathrm{LSD}_{0.05}$ & 15.43 & 32.40 & 1.33 \\
SE & 5.78 & 20.94 & 0.58 \\
\hline
\end{tabular}

\section{Summary and Conclusion}

In this study, an attempt was made to evaluate CWR, WFD and FP under onion production. The evaluation was made by $E_{a}, E_{r}, W U E$, WP and water savings. Tukey's LSD test was used to separate the mean differences. On average, $44.26 \%$ of the water applied to onion field percolated below root zone and not available to the crop production under FP. These considerable $\mathrm{D}_{\mathrm{p}}$ losses under FP implies the wastage of irrigation water; waterlogging and salinity, Ground Water Table rise and leaching of valuable nutrients below root zone may followed (Walker 1989). IWUE is increased by using CWR and WFD which may result in considerable benefits under limited irrigation water availability. Implicitly saved water under the CWR and WFD can be used to irrigate substantial areas and thus address issues of food security and lessen conflicts between head and tail irrigators. CWR technique lead to lesser water input yet was still able to generate onion yield comparable to both WFD and FP.

WFD can save a substantial amount of water without yield reduction of the crops next to the CWR. Although many indicators confirm the importance of CWR approaches, its practicality at farmers level is questioning as it is computer based. Thus, WFD would be an alternative tool to be considered to improve the current on farm water optimization by irrigators.

\section{References}

Allen, R.G., Pereria, L.S., Raes D. and Smith, M. 1998. Crop evapotranspiration. Guidelines for computing crop water requirements. FAO Irriga. and Drain. Paper No. 56. FAO, Rome, Italy.

Amsalu Ayana, Bezabih Emana, Tesfaye Balemi and Milkessa Temesgen. 2014. Scoping study on vegetables seed systems and policy in Ethiopia. The World Vegetable Center. Addis Ababa, Ethiopia.

Doorenbos, J. and Kassam, A.H. 1996. Yield response to water. FAO Irrigation and Drainage Paper No. 33. Pages 111-117. Rome, Italy.

FAO (Food and Agricultural Organization). 1989. Irrigation methods. Irrigation water management training manual No. 5. By Brouwer, C., Prins, K., Kay, M. and Heibloem, M. Rome, Italy.

Gomez, K.A. and Gomez, A.A. 1984. Statistical Procedures for Agricultural Research. John Willey and Sons, NY.

Landon, J.R. 2014. Booker tropical soil manual: a handbook of soil survey and agricultural land evaluation in the tropics. Rootledge, Abingdon, UK.

Lorite, I.J., Mateos, L., Orgaz, F. and Fereres, E. 2007. Assessing deficit irrigation strategies at the level of an irrigation district. Agricultural Water Management 91:51-60.

MoFED (Ministry of Finance and Economic Development). 2006. Ethiopia: Building on Progress. A Plan for Accelerated and Sustained Development to End Poverty (PASDEP). (2005/06-2009/10). Volume I: Main Text. Addis Ababa. 229 pp.

Scherer, T. F., Seeling B. and Franzen, D. 1996. Soil water and plant characteristics important to irrigation. EB66.

Stirzaker, R.J., Etherington, R., Lu, P., Thomson, T. and Wilkie, J. 2005. Improving Irrigation with Wetting Front Detectors. A report for the Rural Industries Research and Development Corporation. RIRDC Publication No 04/176. ISSN 1440-6845. 
Tekalign Tadesse and Haque, I. 1991. Soil, plant, water, fertilizer, animal manure and compost analysis. Working document No. 13. International Livestock Research Centre for Africa, Addis Ababa, Ethiopia.

USDA (United States Department of Agriculture). 1994. Soil Conservation Service. A Productive Nation in Harmony with a Quality Environment: Soil Conservation Service - Strategic Initiatives for the 1990's.

USDA. 2008. Natural Resources Conservation Service. Soil Quality Indicators. Bulk Density.

Walker, W.R. 1989. Guidelines for Design and Evaluating Surface Irrigation System. FAO irrigation and drainage paper 45. Rome, Italy.

Zeleke Agide, Amare Haileslassie, Sally, H., Teklu Erkossa, Schmitter, P., Langan, S. and Hoekstra, D. 2016. Analysis of water delivery performance of smallholder irrigation schemes in Ethiopia: Diversity and lessons across schemes, typologies and reaches. LIVES Working Paper 15. Nairobi, Kenya: International Livestock Research Institute (ILRI).

Zerihun, D., Wang, Z., Rimal, S. and Feyen, J. 1997. Analysis of surface irrigation performance terms and indices. Agricultural Water Management 34: 25-46. 